\title{
THE INTERACTION BETWEEN FOREIGN DIRECT INVESTMENT AND DOMESTIC INVESTMENT: IS THERE CROWDING OUT EFFECT?
}

\author{
Ozge Bolaman Avci \\ Aydın Adnan Menderes University, Turkey \\ Tugba Akin \\ Aydın Adnan Menderes University, Turkey
}

\begin{abstract}
After the fall of communism, Central and Eastern European countries have experienced a transition process in which a remarkable increase is observed in foreign direct investment flows into the region. During this process, when transition countries tried to adopt a free-market economy instead of a closed centrally structured economy, funds obtained through FDI constituted an essential way of financing for these countries that were trying to restructure their economy. This study questions the existence of the crowding-out effect by using data from Eastern European Countries, including Romania, the Russian Federation, Moldova, Poland, Bulgaria, Hungary, Slovak Republic, Ukraine. With this aim, PANIC Bai and Ng (2004), the bias-corrected PANIC Westerlund and Larsson (2009) unit root tests, and panel data analysis are implemented. Results obtained were consistent with theoretical expectations and showed that FDI had a crowding-out effect in the short run but, in the long run, a crowding-in impact on domestic investment.
\end{abstract}

Keywords: Foreign Direct Investment, Domestic Investment, transit economies

DOI: http://dx.doi.org/10.15549/jeecar.v7i2.446

\section{INTRODUCTION}

There is a long debate about the interaction between FDI, economic growth, and domestic investment. During the 1970s, foreign investment, which was charged with generating a monopoly in the industry in which it was invested, was perceived as detrimental to recipient economies (Markusen and Venables,1999, p.336). However, developing economies' perceptions of foreign investment changed in the 1980s. Starting from the mid- 1980s, financial liberalization policies adopted by developing economies caused FDI to trend upward in these countries. Theoretically, FDI has been more advantageous than other types of international capital for the host country since it is less volatile, less prone to reversals, and less exposed to political collateral. According to Lensink and Morrissey (2006), FDI protects recipient countries from unexpected shocks through these advantages. Moreover, as opposed to debt, if FDI is not successful, the 
recipient country does not have a responsibility to pay interest or principal.

Literature examining the nexus between FDI, economic growth and domestic investment can be split into two categories: Studies examining the interaction between FDI and economic growth, and studies examining the existence of the crowding-out effect between FDI and domestic investment. Although there are numerous studies on FDI, the interaction between FDI and domestic investment is relatively less researched. This study will assess the existence of the crowding-out effect by using data from Eastern European Countries. The sample-set includes transition economies that have experienced both political and economic changes after the fall of communism in 1991. In these years, most of these countries have adopted financial liberalization policies in an attempt to integrate with the world economy. The 1990s are also the years when FDI started to become visible.

FDI is defined as a bundle of capital, knowhow, and technology by Balasubramanyam et al. (1999). FDI is considered as beneficial for the supplier economy since profits obtained from FDI are either reinvested or repatriated. Nonetheless, its impact on the recipient economy is controversial, as it depends on the absorption ability of the recipient country. According to De Mello (1999), absorption ability is affected by the host country's trade regime, political stability, legislation, payment constraints, and domestic market size. An earlier study conducted by Abramovitz (1986) identified minimum social capacity, which is highly associated with human capital, economic and political stability, liberalized markets, and sufficient infrastructure as a prerequisite for recipient economies that want to benefit from FDI.

Based on Sun (1998), the interaction between FDI and domestic investment is inconclusive; FDI may stimulate, supplement, or displace domestic investment. Sun (1998) examined the effect of FDI on the host economy in two ways from the supply and demand sides. According to the former, foreign investment may affect the supply of essential resources like machinery, technology, expertise, and financial capital. The latter suggests that FDI affects aggregate demand of the recipient country by initial investment demand and subsequent input demand.

According to Misun and Tomsk (2002), the effect of FDI on domestic investment depends on local country economic policy, the types of FDI received by the host country, and the financial strength of domestic enterprises. When introducing new products to the domestic economy, FDI has been expected to have favorable effects on capital formation. On the contrary, if there are local competitors in the same industry with FDIs, investment opportunities for domestic companies may be eliminated. According to Agosin and Machado (2005), FDI complements domestic investment when foreigners invest in an undeveloped industry of the local economy; however, if there are domestic competitors in the industry invested in, FDI may substitute domestic companies.

Multinational companies have intangible assets that are acquired through experience. These assets, including technological knowhow, export contracts, reputation, marketing, and management skills, are not easily licensed. Still, their transfer to subsidiaries is possible at a reasonable cost (Aitken and Harrison,1999: 607). This transfer becomes possible through FDI. FDI, however, could crowd out domestic investment in the short run. If foreign firms with lower marginal costs increase production and draw demand from domestic firms, local companies may cut production or even leave the industry.

The type of goods produced by a foreign company is another factor to consider in the examination of the crowding-out effect. For instance, if a multinational corporation produces a final good, domestic firms producing the same products will be crowded out. On the other hand, such production could generate a crowding-in effect for local firms providing intermediate goods through upstream externalities. According to DeBacker and Sleuwaegen (2003), FDI may discourage domestic investment in the short run; but through learning, demonstration, networking, and linkage effects, this crowding-out effect can be weakened. Because foreign firms tend to employ the best employees and implement a 
favorable wage structure, many employees who have held well-paying jobs go on to establish their own enterprises in the future. In such a case, FDI will have a significant positive lagged effect on domestic investment. Consequently, based on Barrios (2005), the crowding-out impact in the downstream industries can be compensated by the crowding-in effect experienced in the upstream industries in the long run.

There are many channels of crowding-in. First is the demand-side impact of FDI, the backward linkage effect. The backward linkage effect refers to the supply of inputs by local firms to foreign companies. The host country also benefits from the forward linkage effect, which refers to the provision of efficiency-enhancing inputs by foreign firms to domestic companies (Gallagher \& Zarsky, 2007, p.25). If international corporations produce inputs that are previously imported by local firms, reliance on imports will decrease, which will also improve the trade balance. The recipient economy can also benefit from the multiplier effect. Through the employment provided by foreign firms, local spending on domestically produced goods and services could increase. Moreover, workers employed by foreign companies accumulate knowledge. This human capital, which has been trained by foreigners, becomes available to domestic companies as they exit their former jobs.

Although studies are examining the interaction between foreign direct investment and domestic investment, econometric results are not robust. Reported results vary depending on the data used and the methodology implemented. In this study, the same relationship will be investigated by using data from Eastern European countries, which are transition economies. In particular, the main reason for choosing these countries for this study is that the transition economies have high rates of return in inward FDI, which in turn draws the attention of investors. In fact, the rates of return between 2010-2018 in these countries were nearly 12.4\% (Unctad, 2019:15). For the purpose of this study, the effects of FDI and growth on domestic investment in Eastern European countries were analyzed with panel data analysis using data between 1996-2018.
This study will contribute to the literature due to the lack of studies related to this subject for Eastern European countries and the econometric methods used.

\section{LITERATURE REVIEW}

In the early literature - before 1960 - FDI was treated in the same way as portfolio investment. The motivation for FDI flows was explained as interest rate differentials and rate of return. Hymer (1960) was the first author who differentiate FDI from portfolio investment.

In the 1970s, Internationalization Theory, which is based on Coase's Theory of the Firm (1937) and whose leading proponents were Buckley and Casson (1976) emerged. The Internalization Theory says that firm operations include both production and other activities such as marketing, R\&D, management, and involvement in financial markets. These activities are connected with "intermediate products." If these products' markets are imperfect, it becomes reasonable for firms to internalize them as long as the benefits exceed the costs. Caves (1971) distinguished firms that made horizontal FDI from others that made vertical FDI. Dunning (1977) developed his eclectic paradigm, which states that three factors are critical in determining the international activities of multinationals: Ownership advantages, Locational advantages, and Internalization advantages. Based on the study conducted by Rugman; Buckley and Casson (1976) and Dunning (1980,1981,1988) has formed cornerstones for theory of MNE.

Romer (1993) talked about idea gaps between poor and rich countries. Idea gaps embody many insights regarding packaging, marketing, distribution, inventory control, payment systems, transaction processing, quality control. According to Romer, the idea gap between countries is closed by multinational corporations, which bring new ideas to the domestic economy and combine them with domestic resources. MNCs do this through foreign direct investments, joint ventures, marketing, and licensing agreements. According to Feldstein (1995), who used U.S. data from the 1970 s and 1980s, outbound FDI reduces domestic investment on a dollar-for-dollar 
basis. In contrast, inbound FDI contributes to the domestic investment by the same magnitude.

Aitken and Harrison (1999) asked if domestic firms benefit from foreign direct investment by using data from Venezuela between 1976 and 1989. Empirical results show that wholly domestically owned firms operating in the same industry are affected unfavorably from increases in foreign investment. Misun and Tomsk (2002) asked if the crowding-out effect exists between FDI and domestic investment by using data from the Czech Republic, Hungary and Poland. The authors detected a crowding-out effect/crowding-in effect in Poland/Hungary between 1990 and 2000. A crowding-in effect is also reported in the Czech Republic between 1993-2000. According to Kim and Seo (2003), who investigated the interaction between FDI and economic growth by using Korean data, FDI has a positive but statistically insignificant effect on economic growth. However, economic growth is found to have statistically significant effects on future levels of FDI. Based on their findings, FDI neither crowds-in nor crowds-out domestic investment. In the same year, findings reported by Backer and Sleuwaegen validated the existence of the crowding-out effect in the Belgian manufacturing industry. But the authors also state that the crowding-out effect can be weakened or even reversed in the long run through learning, demonstration, networking, and linkage effects.

Agosin and Machado (2005) questioned the existence of the crowding-out effect for 12 countries in three developing regions. Their paper indicated that FDI, at best, left domestic investment unchanged. The authors concluded the fact that the effects of FDI on domestic investment are not always favorable.

Desai et al. (2005) evaluated the relationship between outward FDI and domestic investment for both OECD countries and U.S. multinationals. According to their results, FDI and domestic investment are substitutes in OECD countries while they are complements for U.S. multinationals. Selvanathan and Selvanathan (2008), who conducted a time series analysis by using data from China, found a complementary relationship between FDI and domestic investment. Morrissey and Udomkerdmongkol (2012) published a paper that not only questioned the existence of the crowding-out effect between FDI and domestic investment but also the role of governance on the relationship between them. Their results proved the existence of a crowding-out effect between FDI and domestic private investment. Farla et al. (2016) questioned the proxies and methodology used by Morrissey and Udomkerdmongkol (2012). They asserted that the findings showing a crowding-out effect would have reversed if proxies and methods improved. Morrissey and Udomkerdmongkol (2016) responded to Farla et al. (2016) and rejected the idea that an improved methodology would provide evidence of a crowding-in effect.

Pilbeam and Oboleviciute (2012) asked if crowding-out exists in the European Union. This study differentiated itself by using data from a common market that guarantees the free movement of goods and services. The authors split the member countries into two groups EU14, including members that have joined European Union before May 2004 (except for Luxembourg), and EU12, those that joined after May 2004. The results showed that, although FDI crowds out domestic investment for older 14 members, it does not have a negative effect on domestic investment in the new EU members in the long run.

Szkorupova (2015) questioned the existence of crowding-in and crowding-out effects for selected countries of Central and Eastern Europe for the years 1993-2012 by using panel regression. Based on their empirical results, FDI crowds out domestic investment.

Polat (2017) examined the impact of total FDI and its financial components (including equity capital investments, reinvested earnings, and intra-company loans) on domestic investment in 30 OECD countries by employing a one-step GMM specification. His results indicated that total FDI inflows do not have a significant effect on domestic investment. Nonetheless, intracompany loans have a positive impact on domestic capital formation; the other two components neither crowd in not crowd out domestic investment.

Yao and Salim (2018) examined the interaction between FDI and domestic investment empirically by using city-level panel data, including the post-WTO period from 2003 
to 2011 in China. According to the empirical results, FDI crowds in domestic investment heavily in eastern China and, to a lesser extent, in central China. In the western cities, a negative but insignificant relationship is detected between the variables.

A recent study conducted by Jude (2019) investigated the same relationship by using data from ten Central and Eastern European Countries from 1995 to 2015. FDI is believed to pose a "creative destruction phenomenon," which refers to a short-term crowding-out effect followed by a crowding-in long-term impact. The type of entry also changes the impact of FDI on domestic investment. The results showed that greenfield FDI, a completely new firm represented by foreign affiliate and acquisition of fixed assets (in addition to capital stock), has a robust crowding-out effect. On the contrary, mergers and acquisitions that refer to a change in ownership of existing assets (without addition to capital stock), do not contribute to capital accumulation. Since greenfield FDI tends to seek trade linkages with domestic firms, it creates a crowding-in effect in the long run.

\section{ANALYSIS}

\section{Data set}

In this study, the effect of foreign direct investments $(\%, \quad F D I / G D P)$ on domestic investments (INV, gross fixed capital formation, current USD) was investigated for the Eastern European Countries of Romania, Russian Federation, Moldova, Poland, Bulgaria, Hungary, Slovak Republic, and Ukraine. In this context, the relationship between INV and FDI was analyzed by using panel data analysis with the auxiliary variables the gross domestic product (G, GDP current USD) and interest rate ( $r$ \% on loan lending) for the period 1996-2018. The annual data was obtained from The World Bank (the World Development Indicators, 2019, Narodowy Bank Polski, Narodna Bank Slovenska, and the Central Bank of The Turkish Republic. The logarithms of INV(LNINV) and G (LNG) were added to the analysis to obtain measurable results with certain elasticity.

\section{Models}

The method suggested by Agosin and Machado (2005: 155) was adopted in this study for research on the effects of $F D I, L N G$, and $r$ on the Eastern European Countries' domestic investment performance; and for this purpose, two models were formed:

Model 1:

$$
\begin{aligned}
& \operatorname{LNINV}_{i t}=\alpha_{0 i}+\alpha_{1 i} L N G_{i t}+\alpha_{2 i} F D I_{i t}+\alpha_{3 i} r_{i t}+ \\
& \alpha_{4 i} L_{N I N V_{i t-1}}+\mu_{i t}
\end{aligned}
$$

Model 2:

$$
\begin{aligned}
& \operatorname{LNINV}_{i t}=\alpha_{0 i}+\alpha_{1 i} F D I_{i t}+\alpha_{2 i} F D I_{i t-1}+ \\
& \alpha_{3 i} L N I N V_{i t-1}+\alpha_{4 i} L N G_{i t}+\alpha_{5 i} L N G_{i t-1}+\alpha_{6 i} r_{i t}+ \\
& \mu_{i t}
\end{aligned}
$$

$i$ denotes countries $(i=1 \ldots, 8)$ and $t$ is time $(t=1,2,3, \ldots, \mathrm{T})$.

\section{Methods}

The empirical analysis was divided into three steps. First, the cross-sectional dependence of countries was analyzed. Following the results of this test, panel unit root tests were conducted on the variables, and finally, panel estimation coefficients were estimated.

\section{The Cross-Sectional Dependence}

The existence of endogenous change that has occurred between countries is checked by using the cross-sectional dependence test. The sustained results for cross-correlation of errors in the panel depends on the shape of the crossdependence (Chudik et al., 2011:46). In line with this, three cross-sectional dependence tests were used in the study. The first one is the Lagrange multiplier (LM) test applicable if $\mathrm{N}$ is small and $\mathrm{T}$ is large, developed by Breusch and Pagan (1980);

$$
L M=T \sum_{i=1}^{N-1} \sum_{j=i+1}^{N} \hat{p}_{i j}^{2}
$$

for $\mathrm{i}=1,2 \ldots, \mathrm{N}$ and $\mathrm{t}=1,2, \ldots, \mathrm{T}$ where $\hat{p}_{i j}^{2}$ is the square of the correlation coefficient. The null hypothesis is "There is no cross-sectional dependence.", and it may refer to the existence 
of correlations between the disturbances in dissimilar cross-section units: $H_{0}=p_{i j}=$ $\operatorname{Corr}\left(\varepsilon_{i t}, \varepsilon_{i j}\right)=0$ for $i \neq j$ and $t \in(i, j)$.

The second one is the Pesaran CD (2004) test applicable even if $\mathrm{N}$ is large and $\mathrm{T}$ is large or one of both is large. This test is expressed as:

$$
\begin{aligned}
& C D=\sqrt{\frac{2 T}{N(N-1)} \sum_{i=1}^{N-1} \sum_{j=i+1}^{N} \hat{p}_{i j}^{2}} \\
& L M_{a d j}=\sqrt{\frac{2 T}{N(N-1)} \sum_{i=1}^{N-1} \sum_{j=i+1}^{N} \hat{p}_{i j}^{2} \frac{(T-k) \hat{p}_{i j}^{2}-\mu_{T i j}}{\sqrt{\hat{v}_{T i j}^{2}}} \sim N(0,1)}
\end{aligned}
$$

The last one is a modified version of the LM test. The bias adjusted LM test was developed by Pesaran et al. (2008). The bias adjusted LM test checks for the sustainable power of exogenous regressors and normal errors in the panel. It also provides more powerful results according to other scholars, such as Akın (2019). The bias adjusted LM test can be formulated as:

$\mu_{T i j}$ and $\hat{v}_{T i j}^{2}$ denote the mean and the variance of the population, respectively. The null hypothesis of the last two tests again is "There is no cross-sectional dependence." The findings of the crosssectional dependence test are given in Table 1.

Table 1: Cross-Sectional Dependence Test

\begin{tabular}{|l|l|l|l|}
\hline Variables & \multicolumn{1}{|c|}{$L M$} & \multicolumn{1}{c|}{$L M_{a d j}$} & \multicolumn{1}{c|}{$C D$} \\
\hline$L N I N V$ & $693.80^{* * *}(0.00)$ & $77.53^{* * *}(0.00)$ & $26.30^{* * *}(0.00)$ \\
\hline$L N G$ & $764.20^{* * *}(0.00)$ & $85.82^{* * *}(0.00)$ & $27.64^{* * *}(0.00)$ \\
\hline$F D I$ & $204.83^{* * *}(0.00)$ & $19.89^{* * *}(0.00)$ & $13.55^{* * *}(0.00)$ \\
\hline$I$ & $529.67^{* * *}(0.00)$ & $58.18^{* * *}(0.00)$ & $22.70^{* * *}(0.00)$ \\
\hline
\end{tabular}

Note: ${ }^{* * *}$ denotes cross-sectional dependence at the $1 \%$ level. Numbers in parentheses are p-values.

According to Table 1, the null hypothesis was strongly rejected for all variables. This is the expected result of a high degree of homogeneity between these countries. It means that a shock in the country spills over to other countries due to high cultural homogeneity and business cycle similarity. Because of cross-sectional dependence, the second-generation panel unit root tests were used in the following section.

\section{Panel Unit Root Test}

The stationarity of panel series was implemented by using the PANIC Bai and $\mathrm{Ng}$ (2004) test, and the bias-corrected PANIC Westerlund and Larsson (2009) test with intercept and linear trend specification. Bai and
$\mathrm{Ng}$ (2004) proposed that the usual Dickey-Fuller limited distribution in idiosyncratic and standard components, and they developed a new methodology named Panel Analysis of Nonstationarity in idiosyncratic and common components (PANIC). The panel unit root test of Bai and $\mathrm{Ng}$ (2004) utilizes the following model with the factor model $\left(F_{t}\right)$ for linear trend (Bai and Ng, 2004: 1137):

$$
\begin{aligned}
& X_{i t}=c_{i}+b_{i} t+\pi_{i} F_{t}+e_{i t} \\
& \Delta X_{i t}=\beta_{i}+\tau_{i} \Delta F_{t}+\Delta e_{i t} \\
& \Delta X_{i t}-\underline{\Delta X_{i}}=\tau_{i}\left(\Delta F_{t}-\underline{\Delta F)}+\left(\Delta e_{i t}-\underline{\Delta e_{i}}\right)\right. \\
& x_{i t}=\tau_{i} f_{t}+z_{i t}
\end{aligned}
$$


The bias-corrected PANIC test has the same model and hypothesis as the PANIC test (Pe). Westerlund and Larsson (2009) indicated that PANIC test results might fall short in providing an asymptotically normal panel unit root test result obtained, and the order of the bias does not disappear as $\mathrm{N}$ increases. Therefore,
Westerlund and Larsson (2009) developed the bias-corrected PANIC test $\left(\mathrm{Ze}^{+}\right)$by constructing the IPS (Im, Peseran \& Shin, 2003) type test (Ze) to improve weaknesses of the PANIC test. The null hypothesis of both tests is "There is a unit root for the Panel." The results of the tests were represented in Table 2.

Table 2: Unit Root Tests

\begin{tabular}{|c|c|c|c|}
\hline Variables & $P e$ & $Z e$ & $Z e^{+}$ \\
\hline$L N I N V$ & $4.84^{* * *}(0.00)$ & $-3.41^{* * *}(0.00)$ & $-2.88^{* *}(0.01)$ \\
\hline$L N G$ & $3.86^{* * *}(0.00)$ & $-3.61^{* * *}(0.00)$ & $-2.46^{* * *}(0.00)$ \\
\hline$F D I$ & $9.44^{* * *}(0.00)$ & $-5.93^{* * *}(0.00)$ & $-4.57^{* * *}(0.00)$ \\
\hline$r$ & $5.87^{* * *}(0.00)$ & $-4.28^{* * *}(0.00)$ & $-3.19^{* * *}(0.00)$ \\
\hline
\end{tabular}

Note: ${ }^{* *}$ and ${ }^{* * *}$ denote cross-sectional dependence at the $5 \%$ and $1 \%$ levels, respectively. Numbers in parentheses are p-values. The maximum number of common factors and lag length is determined as 2.

The panel unit root results show that all variables are stationary at level. This means that the null hypothesis should be rejected for the Eastern European Countries' data at a level so they are integrated into zero, and future exogenous and endogenous shocks to the Eastern European Countries are temporary. Therefore, we conclude that the variables can be used in OLS estimation.

\section{Empirical Results}

Panel data analysis has a double sub-symbol to express variables, and it indicates as;

$$
y_{i t}=\dot{z}_{i}+\beta \dot{x}_{i t}+\mu_{i t}
$$

$i$ signifies the cross-section (e.g. individuals, countries, firms, etc.) and $\mathrm{t}$ signifies time. $z_{i}^{\prime}$ contains a constant term and set of observed or unobserved variables of countries that can be observed (race, sex, location) or unobserved (family-specific characteristics) (Göçer, Akin and Alataş, 2016). There are two methods of OLS regression estimation: the Fixed Effects Model and the Random Effects Model. The fixed-effects model assumes that $Z_{i}$ is correlated with the explanatory variables. This method suggests that differences across countries can be integrated into differences of the constant term (Greene, 2012: 399). However, if there are too many parameters, this model causes a loss of degrees of freedom (Baltagi, 2005:14). To avoid this loss, $\mu_{i}$ can be assumed as random. In other words, $Z_{i}$ will not be correlated with the explanatory variables. The model is calculated as;

$$
\begin{aligned}
& y_{i t}=x_{i t}^{\prime} \beta+E\left[z_{i}^{\prime}\right]+\left\{z_{i}^{\prime}-E\left[z_{i}^{\prime}\right]\right\}+\varepsilon_{i t} \\
& y_{i t}=x_{i t}^{\prime} \beta+\alpha+u_{i}+\varepsilon_{i t}
\end{aligned}
$$

If the sampled cross-sectional countries were drawn from a large population, the randomeffects model would be convenient (Greene, 2012: 411). Implications of model specification and diagnostic tests for fixed and random effects model for both equations (Model 1 and Model 2) are laid out in Table 3 and Table 4. 
Table 3: Model Specification and Diagnostic Tests (Fixed Effects Models)

\begin{tabular}{|c|l|l|}
\hline \multicolumn{1}{|l|}{ Tests } & Model 1 & Model 2 \\
\hline$F_{\text {group }}$ & $11.45(0.00)$ & $3.10(0.00)$ \\
\hline$F_{\text {time }}$ & $8.19(0.00)$ & $2.32(0.00)$ \\
\hline$F_{\text {group+time }}$ & $9.74(0.00)$ & $2.56(0.00)$ \\
\hline$L M_{\text {heteroscedasticity }}$ & $5.99(0.00)$ & $2.74(0.00)$ \\
\hline$L M_{\text {autocorrelation }}$ & $86.80(0.00)$ & $59.29(0.00)$ \\
\hline
\end{tabular}

Note: Numbers in brackets are p-values.

Table 4: Model Specification and Diagnostic Tests (Random Effects Models)

\begin{tabular}{|c|l|l|}
\hline \multicolumn{1}{|l|}{ Tests } & Model 1 & Model 2 \\
\hline$L M_{\text {group }}$ & $51.92(0.00)$ & $2.07(0.15)$ \\
\hline$L M_{\text {time }}$ & $47.63(0.00)$ & $7.82(0.00)$ \\
\hline$L M_{\text {group }+ \text { time }}$ & $99.56(0.00)$ & $9.89(0.00)$ \\
\hline HONDA $A_{\text {group }}$ & $7.21(0.00)$ & $1.43(0.08)$ \\
\hline HONDA $A_{\text {time }}$ & $6.90(0.00)$ & $2.80(0.00)$ \\
\hline HONDA $A_{\text {group }+ \text { time }}$ & $9.98(0.00)$ & $2.99(0.00)$ \\
\hline Hausman & $54.03(0.00)$ & $19.36(0.00)$ \\
\hline$L M_{\text {heteroscedasticity }}$ & $12.61(0.00)$ & $2.02(0.04)$ \\
\hline$L M_{\text {autocorrelation }}$ & $143.01(0.00)$ & $53.19(0.03)$ \\
\hline
\end{tabular}

Note: Numbers in brackets are p-values.

When the results of both tables are examined, using fixed effects and random effects models are more accurate instead of pooled models. The Hausman test will help to decide which fixed effects and random effects model to use. The Hausman test is a useful instrument in determining the preferred specification of the common effects model (Greene, 2012: 420). According to the results of the Hausman tests for both models, the null hypothesis of the random effects model is rejected. The fixedeffect model is the opted specification for these countries' regression analyses. In addition, heteroscedasticity and autocorrelation problems were found in the error terms of the models at the $1 \%$ significance level. Therefore, it was estimated to both models under heteroskedasticity and autocorrelation by using a cross-section SUR method, which estimates a feasible generalized least squares specification while correcting for heteroskedasticity and contemporaneous correlation.

Table 5 shows the coefficients of the panel data obtained for Model 1 and Model 2 . According to Model 1, there is a positive and statistically significant relationship between growth and domestic investment, while the impact of interest rates on domestic investment is negative and significant. 
Table 5: Estimates of Fixed Effects Model

\begin{tabular}{|c|c|c|}
\hline & Model 1 & Model 2 \\
\hline Constant & $-1.8984^{* * *}(0.00)$ & $-0.8606^{* * *}(0.00)$ \\
\hline$L N G$ & $0.7789^{* * *}(0.00)$ & $1.2575^{* * *}(0.00)$ \\
\hline$F D I$ & $0.0504(0.48)$ & $-0.1511^{* * *}(0.00)$ \\
\hline$r$ & $-0.002^{* * *}(0.00)$ & $0.0013^{* * *}(0.00)$ \\
\hline$L N I N V_{t-1}$ & $0.2530^{* * *}(0.00)$ & $0.7244^{* * *}(0.00)$ \\
\hline$L N G_{t-1}$ & - & $-0.9658^{* * *}(0.00)$ \\
\hline$F D I_{t-1}$ & - & $0.1219^{* * *}(0.00)$ \\
\hline
\end{tabular}

Note: ${ }^{* * *}$ denotes cross-sectional dependence at the $1 \%$ level. Numbers in brackets are p-values.

In addition to classical investment function estimation, the lagged values of FDI, LNG and LNINV were also included in Model 2. In this case, the changes in economic activities in the previous period ( $\mathrm{LNINV}_{\mathrm{t}-1}, \mathrm{LNG}_{\mathrm{t}-1,1}$ and $\mathrm{FDI}_{\mathrm{t}-1}$ ) had a significant effect on domestic investments. While the effect of FDI in model 1 is insignificant, it can be seen that in model 2, FDI has a crowding-out effect on domestic investment in the short-term.

\section{DISCUSSION}

The role of FDI in financial and economic development has remarkable policy implications. FDI affects development directly/indirectly as an external source of capital/through its effect on domestic investment. Within the framework of this study, the interaction between FDI and domestic investment is examined. Nonetheless, it is only one effect of FDI on the macroeconomic performance of a recipient country. For policy implications, all direct and indirect macroeconomic impacts of FDI should be considered. Although there are many studies in the literature, empirical results are controversial. The limitation of our study is that the data obtained is not quarterly. With a quarterly data set, the number of observations should be increased, and it should be reconsidered whether the results will change under the presence of structural breaks. In further studies, the financing method of foreign investment could be considered in empirical assessment as in the case in Burçak (2017).
Furthermore, FDI might be categorized as horizontal versus vertical in the empirical part. What is more, the same relationship could be analyzed for not only Eastern European countries but also for developed European countries and results could be given comparatively.

\section{CONCLUSION}

Since the collapse of communism in the late 1980s, transition economies like Eastern European countries left central planning and tried to adopt market capitalism. They have strengthened their financial markets to provide the necessary financing for achieving the intended economic development. These countries have attracted foreign investors through the high domestic demand, growth potential, and high rates of returns they offer. Although FDI constitutes an essential factor for economic development, it alone is not sufficient. To be able to maintain steady economic growth, domestic investment should be increased with FDI. As this is the case, the interaction between foreign direct investment and domestic investment is a topic that is noteworthy to study. Although other research studies are examining the same issue, empirical results vary based on the data used and the methodology implemented. In this study, the relationship between FDI and domestic investment was examined by using data of Eastern European Countries that have offered nearly a $12.4 \%$ rate of return to FDI investors. It was done using panel data analysis, including data from 1996- 
2018. The results show that FDI has a crowdingout effect on domestic savings in the short term but then flipped to having a crowding-in impact in the long run. Our test results were consistent with theoretical expectations. Existing literature also showed that FDI has a crowding-out effect in the short-run but switched to having a crowding-in impact on domestic investment in the long run. Our findings are consistent with De Backer and Sleuwaegen (2003) and Jude (2019).

\section{REFERENCES}

Abramowitz, M. (1986). Catching up, forging ahead and falling behind. The Journal of Economic History, 46, pp.385-406.

Agosin, M. and Machado, R. (2005). Foreign Direct Investment in Developing Countries: Does it Crowd in Domestic Investment? Oxford Development Studies, 33(2), pp. 149162.

Aitken,B. And Harrison, A. (1999). Do Domestic Firms Benefit from Direct Foreign Investment? Evidence from Venezuela. American Economic Review, 89(3), pp. 605618.

Akın, T. (2019). The Effects of Political Stability on Foreign Direct Investment in Fragile Five Countries. Central European Journal of Economic Modeling and Econometrics, 4, pp. 237-255.

Bai, J., and Serena Ng. (2004). A Panic Attack on Unit Roots and Cointegration. Econometrica,72(4), pp. 1127-1177.

Balasubrahmanyam,V.N. and Salisu,M. and Sapsford,D. (1999).Foreign Direct Investment as an engine of growth. Journal of International Trade\&Economic Development, 8(1), pp.27-40.

Baltagi, Badi H. (2005). Econometric Analysis of Panel Data, Third Edition. John Wiley \& Sons, Ltd., England.

Barrios, S., Görg, H. and Strobl, E. (2005). Foreign direct investment, competition and industrial development in the host country. European Economic Review, 49(7), pp. 1761-1784.
Breusch, T. S., and Pagan A.R. (1980). The Lagrange multiplier test and its applications to model specification in econometrics. The review of economic studies, 47(1), pp. 239253.

Buckley, P. and Casson, M. (1976). The Future of the Multinational Enterprise, (London: Macmillan, 1976)

Caves, R. E.(1971).Industrial Corporations: The Industrial Economics of Foreign Investment, Economica, 38,pp. 1-27

Chudik, A., Pesaran M. H., and Tosetti, E. (2011). Weak and strong cross-section dependence and estimation of large panels. The Econometrics Journal,14(1), pp. 45-90.

Coase, R. H. (1937). The nature of the firm. Economica (New series), 4, pp.387-405.

De Mello, L. (1999). Foreign Direct InvestmentLed Growth: Evidence from Time Series and Panel Data. Oxford Economic Papers, 51(1), pp.133-151.

Debacker, K. and Sleuwaegen, L. (2003). Does Foreign Direct Investment Crowd Out Domestic Entrepreneurship? Review of Industrial Organization, 22(1), pp.67-84.

Desai,M., Foley, C.H. and Hines, J.(2005). Foreign Direct Investment and The Domestic Capital Stock, American Economic Review, 95(2), pp.33-38.

Dunning, J. H. (1977). Trade, location of economic activity and the MNE: A search for an eclectic approach. In the International Allocation of Economic Activity (pp. 395418). Palgrave Macmillan, London.

Dunning, J.H. (1980). Toward an eclectic theory of international production: some empirical tests. Journal of International Business Studies 11(1), pp.931.

Dunning, J.H. (1981). International production and the multinational enterprise. London: Allen and Unwin.

Dunning, J.H. (1988). Explaining international production. London: Unwin Hyman.

Farla,K., Crombrugghe, D. And Verspagen, B. (2016). Institutions, Foreign Direct Investment, and Domestic Investment: 
Crowding Out or Crowding In? World Development, Vol.88, pp.1-9.

Feldstein, M. (1995). The Effects of Outbound Foreign Direct Investment on the Domestic Capital Stock, M. Feldstein, J. Hines and R.G. Hubbard (eds.) The Effects of Taxation on Multinational Corporations, University of Chicago Press: Chicago, pp: 43-63.

Gallagher, K.P. and Zarsky, L. (2007). The Enclave Economy, The MIT Press

Gocer, I., Akin, T. and Alatas, S. (2016). The effects of saving-investment gap on economic growth in developing countries: A clustering and panel data analysis. Theoretical \& Applied Economics,2(607), pp.157-172.

Greene, W. H. (2012). Econometric Modeling, Seventh Edition. Pearson Education Limited, England.

Hymer, S. (1960). The International Operations of National Firms: A Study of Foreign Direct Investment, Massachusetts Institute of Technology: MIT Press.

Im K.S., Pesaran M.H., Shin Y. (2003). Testing for unit roots in heterogeneous panels. Journal of Econometrics, 115(1), pp.53-74.

Jude, C. (2019). Does FDI Crowd Out Domestic Investment in Transition Economies? Economics of Transition and Institutional Change, 27(1), pp.163-200.

Kim, D. D. and J.-S. Seo (2003). Does FDI Inflow Crowd Out Domestic Investment in Korea? Journal of Economic Studies, 30(6), pp.605622.

Lensink, R. and Morrissey, O. (2006). Foreign Direct Investment: Flows, Volatility, and the Impact on Growth. Review of International Economics, 14(3), pp.478-493.

Misun, J. and Tomsk, V. (2002). Does Foreign Direct Investment Crowd in or Crowd Out Domestic Investment? Eastern European Economics, 40(2), pp.38-56.

Morrissey,O. And Udomkerdmongkol, M. (2012). Governance, Private Investment and Foreign Direct Investment in Developing Economies, World Development, 40(3), pp.437-445

Pesaran, M.H. (2004). General diagnostic tests for cross section dependence in panels.
CESifo Working Papers, No.1233, pp. 25560.

Pesaran M.H., Ullah A., Yamagata T. (2008). A bias adjusted LM test of error cross-section independence. The Econometrics Journal, 11(1), pp.105-127.

Pilbeam, K. and Oboleviciute, N. (2012). Does Foreign Direct Investment Crowd in or Crowd out Domestic Investment? Evidence from European Union. The Journal of Economic Asymmetries, 9(1), pp.89-104.

Polat, B. (2017). Do Foreign Investors Crowd out or Crowd in Domestic Investment? A Panel Analysis for OECD Countries, Book Citation Index , Web of Science (BKCI), DOI. http://dx.doi.org/10.5772/intech open.68856, ISBN 978-953-51-54624, Emerging Issues in Economics and Development, Edited by.Jega Ibrahim Musa, Publisher, InTechOpen

Romer, P.(1993).Idea Gaps and Object Gaps in Economic Development, Journal of Monetary Economics, 32(3), pp.543-573

Rugman, A.M. (2010). Reconciling internalization theory and the eclectic paradigm. Multinational Business Review,18, pp.1- 12.

Selvanathan, S. And Selvanathan,S. (2008).Foreign Direct Investment, Domestic Investment and Economic Growth in China: A Time Series Analysis, The World Economy, 31(10), pp.1292-1309.

Sun, H. (1998). Foreign Direct Investment and Economic Growth in China:1979-1996, New York: Ashgate Publishing

Szkorupova, Z. (2015). Relationship between Foreign Direct Investment and Domestic Investment in Selected Countries of Central and Eastern Europe, Procedia Economics and Finance,23, pp.1017-1022.

Unctad (2019). World Investment Report 2019. https://unctad.org/en/pages/PublicationWeb flyer.aspx ?publicationid=2460 Access Dated: 02.08.2019

Westerlund, J. and Larsson, R. (2009). A note on the pooling of individual PANIC unit root tests. Econometric Theory, 25(6), pp.18511868. 
Yao, Y. And Salim, R. (2018). Crowds in or crowds out? The effect of foreign direct investment on domestic investment in Chinese cities, Empirical Economics, doi:10.1007/s00181-018-1611-8.

\section{ABOUT THE AUTHORS}

Tugba Akin, email: tugba.akin@adu.edu.tr

Dr. Tugba Akin is an is an Assistant Professor in Econometrics at the Aydin Adnan Menderes University. She got her bachelor degree in economics at Middle East Technical University, master's degree in economics at Uludag University and Phd in Aydın Adnan Menderes University. Her research interests include macroeconomics, economic growth and development, applied econometrics, political instability and agricultural economics. ORCID Number: https://orcid.org/ 0000-0002-1132-388X

Dr. Ozge Bolaman Avci is an Assistant Professor, Faculty of Economics at Adnan Menderes University. She got her Ph.D. from Dokuz Eylül University, İzmir in 2015. Her research interest includes international finance and behavioural finance. ORCID Number: https://orcid.org/0000-0001-51194624 